\title{
PENGARUH KUALITAS LAYANAN DAN CITRA PERUSAHAAN TERHADAP LOYALITAS KONSUMEN LION AIR DI KOTA BANDUNG DENGAN KEPUASAN SEBAGAI VARIABEL INTERVENING
}

\author{
Rozy Fauzana ${ }^{1}$, Putu Nina Madiawati ${ }^{2}$ \\ ${ }^{1}$ Fakultas Komunikasi dan Bisnis, Universitas Telkom \\ email: rozyfauzana18@gmail.com \\ ${ }^{2}$ Fakultas Komunikasi dan Bisnis, Universitas Telkom \\ email: pninamad@gmail.com
}

\begin{abstract}
The purpose of this research is to determine the effect of Service Quality, Corporate Image on Lion Air Consumer Loyalty in Bandung with Consumer Satisfaction as intervening variable. Method in this researchis kuantitatif method with descriptive causal research type. Samples was conducted by non probability sampling method of purposive sampling with 100 respondents. Technique descriptive analysis and path analysis. The results of the descriptive analysis showed that the variable image of Service Quality, Corporate Image, Consumer Satisfaction and Consumer Loyalty are in pretty good category. The result of path analysis calculation shows that the variable of Service Quality and Corporate Image together influence on Consumer Loyalty variable through the Consumer Satisfaction of Lion Air in Bandung.

Keywords: Service Quality, Corporate Image, Consumer Satisfaction, Consumer Loyalty
\end{abstract}

Abstrak :Tujuan dilakukan penelitian ini untuk mengetahui pengaruh Kualitas Layanan, Citra Perusahaan terhadap Loyalitas Konsumen Lion Air di Kota Bandung dengan Kepuasan Konsumen sebagai Variabel Intervening. Metode pada penelitian ini adalah metode kuantitatif dengan jenis penelitian deskriptif kausal. Sampel diambil dengan metode non probability sampling jenis purposive sampling dengan jumlah responden 100 orang. Teknik analisis data yang dalam penelitian ini adalah analisis deskriptif dan path analysis. Hasil penelitian dari analisis deskriptif menunjukkan variabel Kualitas Layanan, Citra Perusahaan, Kepuasan Konsumen dan Loyalitas Konsumen berada pada kategori cukup baik. Hasil perhitungan analisis jalur menunjukkan bahwa variabel Kualitas Layanan dan Citra Perusahaan secara bersama-sama berpengaruh terhadap Loyalitas Konsumen Lion Air di Kota Bandung melalui variabel Kepuasan Konsumen.

Kata kunci: Kualitas Layanan, Citra Perusahaan, Kepuasan Konsumen, Loyalitas Konsumen

\section{A. PENDAHULUAN}

\subsection{Latar Belakang}

Lion Air merupakan maskapai penerbangan di Indonesia dengan penumpang terbanyak. Hal tersebut dapat dilihat dari data jumlah penumpang angkutan udara domestik kuartal 1 tahun 2019 dimana Lion Air memiliki jumlah penumpang 5,457,261 penumpang, Garuda Indonesia sebanyak 3,503,834 penumpang, Citilink sebanyak 2,993,578 penumpang dan Batik Air sebanyak

2,474,255 penumpang (tirto.id). Meskipun Lion Air memiliki penumpang paling banyak, dalam artikel yang berjudul "Buruknya Pelayanan Lion Air, dari Delay Hingga Mati Mesin yang Menyiksa Penumpang" yang dimuat pada website sulselsatu.com tahun 2018 yang menyatakan bahwa kejadian buruk yang dialami penumpang, mulai dari jadwal keberangkatan pesawat dari pukul 18.40 WIB mengalami delay hingga pukul 20.00 WIB, penumpang dibuat panik saat melakukan take off dimana mesin pesawat yang tiba-tiba mati sampai tiga kali setelah diisi daya dan penumpang merasa kepanasan karena $\mathrm{AC}$ di dalam pesawat tidak jalan, sehingga penumpang memaksakan diri untuk turun pesawat. Hal ini menunjukkan bahwa buruknya kualitas layanan Lion Air yang menyebabkan ketidak puasan konsumen. Lion Air mempunyai 
catatan buruk di sektor penerbangan , mulai dari ledakan di belakang pesawat, pesawat tergelincir dan bahkan jatuh ketika mengudara. Masalah tersebut membuat kurangnya kepercayaan publik terhadap maskapai pernerbangan Lion Air (finance.detik.com). Hal tersebut berdampak pada citra baik Lion Air karena citra merupakan persepsi atau pandangan masyarakat terhadap perusahaan. Selain itu pada website merdeka.com dengan judul "Lion Air tak pernah respons keluhan konsumen" yang dimuat pada November 2018 dikomentari oleh penumpang dengan berbagai keluhan tentang penumpang yang tidak ingin menggunakan Lion Air lagi.

Peneliti melakukan pra survei mengenai Kualitas Layanan, Citra Perusahaan, Kepuasan Konsumen dan Loyalitas Konsumen Lion Air kepada 15 orang konsumen Lion Air di Kota Bandung. Dilakukan survei untuk melihat masalah yang muncul antara variabel-variabel tersebut. Hasil menunjukkan bahwa variabel Loyalitas Konsumen pada indikator repeat purchase yaitu saya setia dengan penerbangan Lion Air dengan $80 \%$ responden menjawab tidak dan pernyataan mengenai indikator retention yaitu saya tidak terpengaruh dengan tawaran jasa penerbangan lain selain Lion Air dengan 73,3\% responden menjawab tidak. Variabel Kepuasan Konsumen pada indikator kesesuaian harapan pelayanan yang diberikan Lion Air sesuai dengan kebutuhan saya dengan 53,3\% yang menjawab tidak dan pernyataan tentang indikator kesediaan merekomendasikan yaitu saya akan merekomendasikan Lion Air kepada orang lain dengan 66,7\% responden menjawab tidak. Variabel Kualitas Layanan pada indikator reliability yaitu Lion Air selalu tepat waktu dalam keberangkatan dengan 86,7\% responden menjawab tidak dan pernyataan mengenai indikator reputation yaitu Lion Air cepat menanggapi keluhan penumpang dengan 60\% responden menjawab tidak. Dan variabel Citra Perusahaan pada indikator personality yaitu Lion Air merupakan jasa penerbangan yang terpercaya dengan 53,3\% responden yang menjawab tidak.

\subsection{Rumusan Masalah}

Rumusan masalah berdasarkan latar belakang diatas yaitu sebagai berikut:

1. Bagaimana kualitas layanan Lion Air?

2. Bagaimana citra perusahaan Lion Air?

3. Bagaimana kepuasan konsumen Lion Air?

4. Bagaimana loyalitas konsumen Lion Air?

5. Berapa besar hubungan kualitas layanan dan citra perusahaan Lion Air?

6. Berapa besar pengaruh kualitas layanan terhadap kepuasan konsumen Lion Air?

7. Berapa besar pengaruh citra perusahaan terhadap kepuasan konsumen Lion Air?

8. Berapa besar pengaruh kualitas layanan terhadap loyalitas konsumen Lion Air?

9. Berapa besar pengaruh citra perusahaan terhadap loyalitas konsumen Lion Air?

10. Berapa besar pengaruh kepuasan konsumen terhadap loyalitas konsumen Lion Air?

11. Berapa besar pengaruh kualitas layanan dan citra perusahaan terhadap kepuasan konsumen Lion Air secara simultan?

12. Berapa besar pengaruh kualitas layanan, citra perusahaan dan kepuasan secara simultan terhadap loyalitas konsumen Lion Air?

13. Berapa besar pengaruh kualitas layanan dan citra perusahaan terhadap loyalitas konsumen Lion Air melalui kepuasan konsumen?

\subsection{Tujuan Penelitian}

Tujuan penelitian pada penelitian ini adalah untuk mengetahui :

1. Kualitas layanan Lion Air.

2. Citra perusahaan Lion Air.

3. Kepuasan konsumen Lion Air.

4. Loyalitas konsumen Lion Air.

5. Besarnya hubungan kualitas layanan dan citra perusahaan Lion Air.

6. Besarnya pengaruh kualitas layanan terhadap kepuasan konsumen Lion Air.

7. Besarnya pengaruh citra perusahaan terhadap kepuasan konsumen Lion Air.

8. Besarnya pengaruh kualitas layanan terhadap loyalitas konsumen Lion Air. 
9. Besarnya pengaruh citra perusahaan terhadap loyalitas konsumen Lion Air.

10. Besarnya pengaruh kepuasan konsumen terhadap loyalitas konsumen Lion Air.

11. Besarnya pengaruh kualitas layanan dan citra perusahaan terhadap kepuasan konsumen Lion Air secara simultan.

12. Besarnya kualitas layanan, citra perusahaan dan kepuasan secara simultan terhadap loyalitas konsumen Lion Air.

13. Besarnya pengaruh kualitas layanan dan citra perusahaan terhadap loyalitas konsumen Lion Air melalui kepuasan konsumen.

\section{Tinjauan Pustaka}

\subsection{Kualitas Layanan}

Menurut Tjiptono \& Chandra (2017: 90) : kualitas layanan merupakan perbandingan antara tingkat layanan yang disampaikan perusahaan dengan harapan pelanggan. Dalam kasus pemasaran jasa, dimensi kualitas yang paling sering dijadikan acuan adalah: (Tjiptono \& Chandra, 2017:89)

1. Reliability: keandalan dalam memberikan layanan yang telah dijanjikan

2. Responsivitas: kemampuandan kepekaan perusahaan dalam melayani pelanggan secara tanggap.

3. Assurance: merupakan kepastian jdan jaminan yang diberikan kepada pelanggan.

4. Empathy: menjalin hubungan dengan mudah dengan pelanggan dengan memberikan perhatian yang tulus.

5. Tangible: merupakan bukti fisik perusahaan seperti perlengkapan, fasilitas perusahaan, karyawan.

\subsection{Citra Perusahaan}

Menurut Abdul Majid (2018:69) Citra Perusahaan merupakan pandangan masyarakat tentang baik buruknya suatu perusahaan.

Menurut Harrison dalam Kusuma (2018:29) Citra perusahaan terdiri dari empat elemen, yaitu:

1. Personality : merupakan karakteristik perusahaan yang dikenal masyarakat seperti perusahaan dengan tanggung jawab sosial dan dapat dipercaya.

2. Reputation : keyakinan publik sasaran berdasarkan pengalaman terhadap hal yang telah dilakukan perusahaan atau kinerja perusahaan.

3. Value : merupakan nilai yang terdapat pada perusahaan

4. Corporate Identity: identitas perusahaan yang memudahkan masyarakat mengenal perusahaan seperti slogan, logo dan warna.

\subsection{Kepuasan Konsumen}

Menurut Kotler kepuasan pelanggan merupakan perbandingan kinerja yang telah dirasakan dengan yang diharapkan pelanggan (Windasuri \& Susanti, 2016:64).

Atribut pembentuk kepuasan konsumen menurut Hawkins \& Lonney dalam Fandy Tjiptono (2016:101) terdiri dari:

1. Kesesuaian harapan : kesesuaian antara kinerja yang diharapakan konsumen dengan yang dirasakannya.

2. Minat berkunjung kembali: kesediaan konsumen untuk melakukan pembelian ulang atau kembali berkunjung

3. Kesediaan merekomendasikan : kemauan atau keinginan konsumen untuk merekomendasikan perusahaan kepada orang lain.

\subsection{Loyalitas Konsumen}

Loyalitas merupakan kesediaan konsumen untuk terus menerus berlangganan pada perusahaan (Utama, 2017: 205 ).

Indikator loyalitas pelanggan ( Kotler dan Keller , 2016:57) adalah sebagai berikut: 
1. Repeat Purchase : kesetiaan konsumen terhadap produk secara terus menerus.

2. Retention : ketahanan terhadap pengaruh dari segala bentuk pemasaran dari perusahaan lain

3. Referrals: konsumen mereferensikan perusahaan sesuai dengan yang dirasakannya.

\subsection{Kerangka Pemikiran Penelitian}

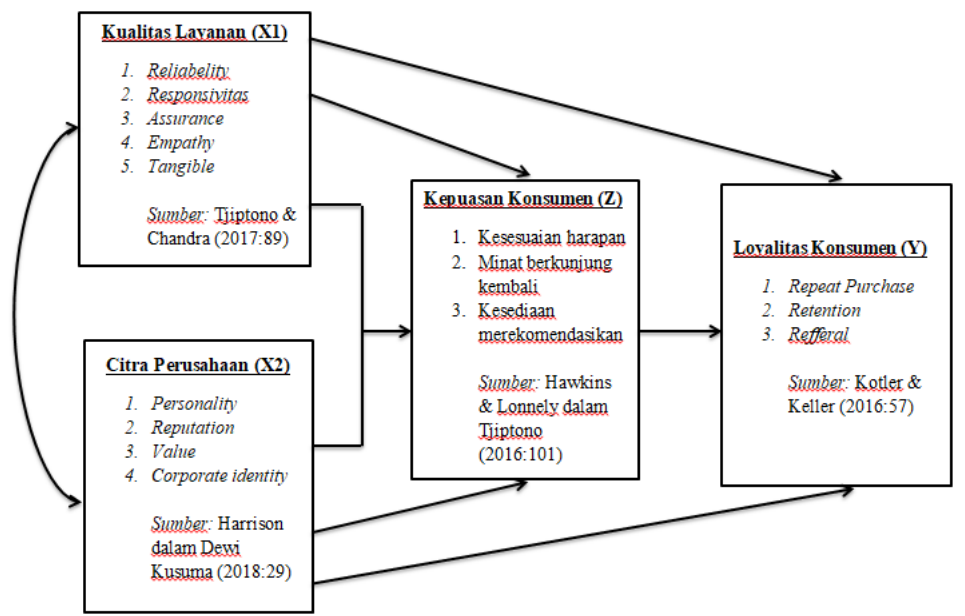

Gambar 2.1 Kerangka Pemikiran Penelitian

Hipotesis pada peenelitian ini adalah:

$\mathbf{H}_{1}$ : $\quad$ Kualitas layanan berpengaruh terhadap kepuasan konsumen Lion Air di Kota Bandung.

$\mathbf{H}_{2}$ : Citra perusahaan berpengaruh terhadap kepuasan konsumen Lion Air di Kota Bandung.

$\mathbf{H}_{3}$ : $\quad$ Kualitas layanan berpengaruh terhadap loyalitas konsumen Lion Air di Kota Bandung.

$\mathbf{H}_{4}$ : $\quad$ Citra perusahaan berpengaruh terhadap loyalitas konsumen Lion Air di Kota Bandung.

$\mathbf{H}_{5}$ : Kepuasan konsumen berpengaruh terhadap loyalitas konsumen Lion Air di Kota Bandung.

$\mathbf{H}_{6}$ : Kualitas layanan dan citra perusahaan berpengaruh berpengaruh terhadap kepuasan konsumen Lion Air di Kota Bandung secara simultan.

$\mathbf{H}_{7}$ : Kualitas layanan, citra perusahaan dan kepuasan konsumen berpengaruh secara simultan terhadap loyalitas konsumen Lion Air di Kota Bandung.

$\mathbf{H}_{\mathbf{8}}$ : $\quad$ Kualitas layanan dan citra perusahaan berpengaruh terhadap loyalitas konsumen Lion Air di Kota Bandung melalui kepuasan konsumen.

\section{B. METODE PENELITIAN}

Jenis penelitian pada penelitian ini adalah deskriptif dan kausal dengan pendekatan kuantitatif. Penelitian deskriptif digunakan untuk mengetahui nilai variabel mandiri, satu atau lebih variabel tanpa membuat perbandingan atau menghubungkan variabel satu dengan yang lainnya (Sugiyono 2014:11). Penelitian kausal menurut Sugiyono (2019:66) adalah penelitian yang bertujuan menganalisis hubungan sebab akibat antara variabel dependen dan variabel independen. Metode penelitian kuantitatif menurut Sugiyono (2019:17) yaitu metode penelitian yang berlandaskan pada filsafat positif yang digunakan untuk meneliti populasi atau sampel tertentu, teknik pengambilan sampel umumnya dilakukan secara acak, data dikumpulkan menggunakan instrumen penelitian, analisis data bersifat kuantitatif dengan tujuan untuk menguji hipotesis yang telah ditetapkan.

Berikut ini adalah tahapan penelitian yang akan dilakukan: 


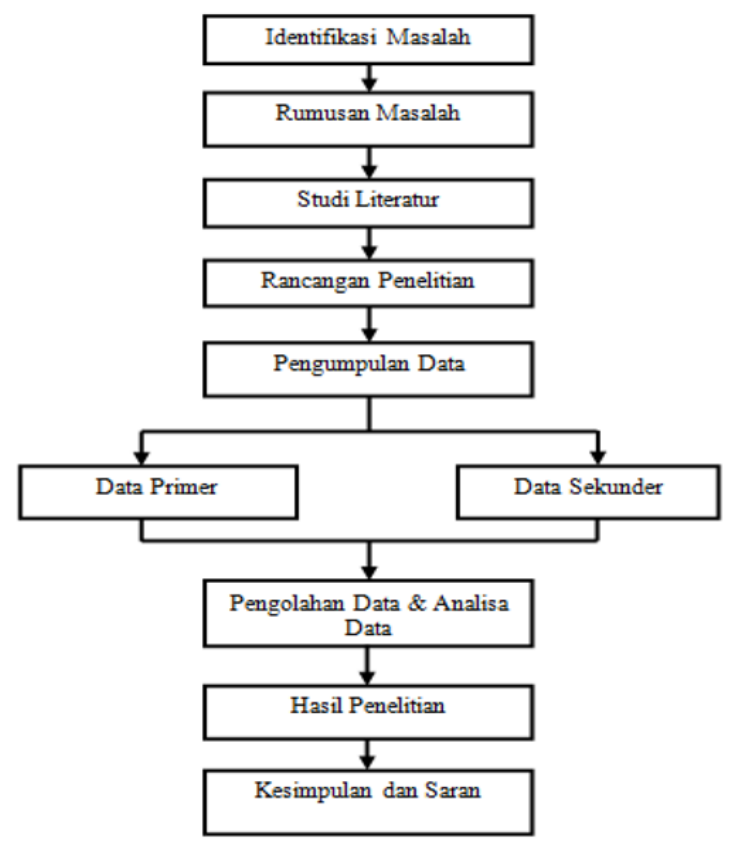

Gambar 2.1 Tahapan Penelitian

Sumber : Sugiyono (2012:47)

Lokasi pada penelitian ini adalah Kota Bandung, dengan objek penelitian konsumen maskapai penerbangan Lion Air. Teknik sampling yang digunakan adalah non-probability sampling dengan sampling purposive. Non- probability sampling merupakan teknik pengambilan sampel yang tidak memberi peluang yang sama bagi setiap anggota populasi untuk dipilih menjadi sampel (Sugiyono, 2019: 131). Sampling purposive yaitu teknik menentukan sampel dengan pertimbangan tertentu (Sugiyono, 2019: 133).

Penelitian ini terdapat 3 variabel yang digunakan, yaitu:

1. Dependent Variable, adalah variabel yang menjadi perhatian utama pada penelitian, merupakan variabel yang langsung dipakai menjawab masalah penelitian (Indrawati, 2015:73). Dependent variabel yang dimaksud pada penelitian ini adalah Loyalita Konsumen (Y).

2. Independent Variable, merupakan variabel yang langsung dipakai menjawab masalah peneliti, variabel ini langsung mempengaruhi dependent variable secara positif taupun negatif (Indrawati, 2015:73). Independent Variable yang dimaksud pada penelitian ini adalah Kualitas Layanan $\left(\mathrm{X}_{1}\right)$ dan Citra Perusahaan $\left(\mathrm{X}_{2}\right)$.

3. Intervening Variable, adalah variabel yang muncul ketika variabel dependen dipengaruhi oleh variabel independen, variabel ini membantu menjelaskan pengaruh independen variable terhadap dependen variable (Indrawati, 2015:74). Intervening Variable pada penelitian ini adalah Kepuasan Pelanggan (Z).

\section{HASIL DAN PEMBAHASAN}

\subsection{Hasil}

Pengumpulan data dilakukan melalui penyebaran kuesioner ke 100 orang responden dan didapat hasil sebagai berikut:

\subsubsection{Tanggapan mengenai Kualitas Layanan, Citra Perusahaan, Kepuasan Konsumen} dan Loyalitas Konsumen.

Berikut merupakan hasil analisis deskriptif:

a. Kualitas Layanan Lion Air secara keseluruhan masuk dalam kategori cukup baik dengan besar persentase $65 \%$.

b. Citra Perusahaan berada dalam kategori cukup baik dengan besar persentase $62,6 \%$. 
c. Kepuasan Konsumen berada dalam kategori cukup baik dengan besar persentase $58,2 \%$.

d. Loyalitas Konsumen berada dalam kategori tidak baik dengan besar persentase $51,4 \%$.

\subsubsection{Path Analysis (Analisis Jalur )}

Path analysis digunakan untuk menganalisis hubungan sebab dan akibat yang inheren, antar variabel yang disusun berdasarkan urutan temporer dan menggunakan koefisien jalur sebagai besaran nilai untuk menentukan besarnya pengaruh independen variable terhadap dependen variable (Jonathan 2012:17).

\section{a. Uji Sub-Struktur 1}

Uji sub-struktur 1: Adanya pengaruh Kualitas Layanan dan Citra Perusahaan secara simultan dan signifikan terhadap Kepuasan Konsumen.

Persamaan $1: Z=\rho z x_{1} X_{1}+\rho z x_{2} X_{2}+\rho \varepsilon_{1}$ (sub-struktur 1).

\section{1) Secara Simultan}

Berdasarkan tabel Anova didapat nilai Fhitung 128,160 lebih besar dari Ftabel untuk $\alpha=$ 0,05 sebesar 2,47 dengan nilai probabilitas $(\mathrm{sig})=0,000$. Karena Fhitung $(128,160)>$ Ftabel $(2,47)$ maka disimpulkan bahwa $\mathrm{H}_{0}$ ditolak dan $\mathrm{H}_{\mathrm{a}}$ diterima yang maksudnya adalah secara bersama-sama Kualitas Layanan $\left(\mathrm{X}_{1}\right)$ dan Citra Perusahaan $\left(\mathrm{X}_{2}\right)$ berpengaruh secara simultan dan signifikan terhadap Kepuasan Konsumen (Z).

2) Parsial

Tabel 3.1

Coefficients ${ }^{\mathrm{a}}$ Sub-Struktur 1

\begin{tabular}{|c|c|c|c|c|c|}
\hline \multirow[t]{2}{*}{ Model } & \multicolumn{2}{|c|}{$\begin{array}{c}\text { Unstandardized } \\
\text { Coefficients }\end{array}$} & \multirow{2}{*}{$\begin{array}{c}\begin{array}{c}\text { Standardized } \\
\text { Coefficients }\end{array} \\
\text { Beta }\end{array}$} & \multirow[t]{2}{*}{$\mathrm{t}$} & \multirow[t]{2}{*}{ Sig. } \\
\hline & B & $\begin{array}{l}\text { Std. } \\
\text { Error }\end{array}$ & & & \\
\hline (Constant) & -1.991 & 1.302 & & -1.529 & .130 \\
\hline KL & .168 & .054 & .245 & 3.137 & .002 \\
\hline $\mathrm{CP}$ & .717 & .085 & .656 & 8.408 & .000 \\
\hline
\end{tabular}

Sumber : Pengolahan SPSS, 2020

Berdasarkan tabel 3.1 dapat dilihat bahwa:

a. Variabel Kualitas Layanan $\left(\mathrm{X}_{1}\right)$ nilai t hitung $(3,137)>$ ttabel $(1,985)$ dengan sig $0,002<$ 0,05 maka $\mathrm{H}_{0}$ ditolak dan $\mathrm{H}_{\mathrm{a}}$ diterima yang artinya Kualitas Layanan $\left(\mathrm{X}_{1}\right)$ berpengaruh secara signifikan terhadap Kepuasan Konsumen (Z).

b. Variabel Citra Perusahaan $\left(\mathrm{X}_{2}\right)$ nilai $\mathrm{t}$ hitung $(8,408)>\mathrm{t}$ tabel $(1,985)$ dengan sig $0,000<$ 0,05 maka $\mathrm{H}_{0}$ ditolak dan $\mathrm{H}_{\mathrm{a}}$ diterima yang artinya Citra Perusahaan $\left(\mathrm{X}_{1}\right)$ berpengaruh secara signifikan terhadap Kepuasan Konsumen (Z).

3) Koefisien Determinasi

Berdasarkan tabel Model Summary besar nilai R square yaitu 0,725 atau dengan perhitungan rumus koefisien determinasi yaitu:

$$
\begin{aligned}
\mathrm{KD}_{\text {Sub-Struktur } 1}=\mathrm{R}^{2} \times 100 \%=(0,852)^{2} & \times 100 \% \\
& =0,725 \times 100 \% \\
& =72,5 \%
\end{aligned}
$$

Artinya adalah besar pengaruh variabel Kualitas Layanan $\left(\mathrm{X}_{1}\right)$ dan Citra Perusahaan $\left(\mathrm{X}_{2}\right)$ terhadap Kepuasan Konsumen (Z) sebesar 72,5\%, sedangkan sisanya 27,5\% dipengaruhi oleh variabel lain.

\section{b. Uji Sub-Struktur 2}

Uji sub-struktur 2 : Adanya pengaruh Kualitas Layanan $\left(\mathrm{X}_{1}\right)$ dan Citra Perusahaan $\left(\mathrm{X}_{2}\right)$ terhadap Loyalitas (Y) melalui Kepuasan Konsumen (Z). 
Persamaan $2: \mathrm{Y}=\rho \mathrm{y} \boldsymbol{x}_{1} \boldsymbol{X}_{1}+\rho \mathrm{y} \boldsymbol{x}_{2} \boldsymbol{X}_{2}+\rho \mathrm{Z}+\boldsymbol{\rho} \boldsymbol{\varepsilon}_{2}$ (sub-struktur 2).

\section{Secara Simultan}

Berdasarkan tabel Anova besar nilai F hitung 79,143 besar dari Ftabel untuk $\alpha=0,05$ sebesar 2,47 dengan nilai probabilitas (sig) $=0,000$. Karena Fhitung $(79,143)>F$ tabel $(2,47)$ Maka dapat dikatakan bahwa $\mathrm{H}_{0}$ ditolak dan $\mathrm{H}_{\mathrm{a}}$ diterima yang maksudnya adalah secara bersama-sama Kualitas Layanan (X1), Citra Perusahaan (X2) dan Kepuasan Konsumen (Z) berpengaruh secara simultan dan signifikan terhadap Loyalitas Konsumen (Y).

\section{Parsial}

\section{Tabel 3.3}

\section{Coefficients Sub-Struktur 2}

\begin{tabular}{|c|c|c|c|c|c|}
\hline \multicolumn{6}{|c|}{ Coefficients $^{\mathrm{a}}$} \\
\hline \multirow[t]{2}{*}{ Model } & \multicolumn{2}{|c|}{$\begin{array}{c}\text { Unstandardized } \\
\text { Coefficients }\end{array}$} & $\begin{array}{l}\text { Standardized } \\
\text { Coefficients }\end{array}$ & \multirow[t]{2}{*}{$\mathrm{t}$} & \multirow[t]{2}{*}{ Sig. } \\
\hline & B & $\begin{array}{l}\text { Std. } \\
\text { Error }\end{array}$ & Beta & & \\
\hline (Constant) & 2.049 & 1.249 & & 1.640 & .104 \\
\hline KL & .165 & .053 & .260 & 3.084 & .003 \\
\hline $\mathrm{CP}$ & .264 & .106 & .263 & 2.486 & .015 \\
\hline KK & .729 & .096 & .792 & 7.573 & .000 \\
\hline
\end{tabular}

a. Dependent Variable: LK

Sumber : Pengolahan SPSS, 2020

Dalam tabel 3.3 Coefficient tersebut dapat dilihat bahwa:

a. Variabel Kualitas Layanan $\left(\mathrm{X}_{1}\right)$ nilai t hitung $(3,084)>$ ttabel $(1,985)$ dan sig $0,003<0,05$ maka H0 ditolak dan Ha diterima yang maksudnya Kualitas Layanan $\left(\mathrm{X}_{1}\right)$ berpengaruh signifikan terhadap Loyalitas Konsumen (Y).

b. Variabel Citra Perusahaan $\left(X_{2}\right)$ nilai t hitung $(2,486)>$ ttabel $(1,985)$ dan sig $0,015>0,05$ maka H0 ditolak dan Ha diterima yang artinya Citra Perusahaan $\left(\mathrm{X}_{2}\right)$ berpengaruh secara signifikan terhadap Loyalitas Konsumen (Y).

c. Variabel Kepuasan Konsumen (Z) nilai t hitung $(7,573)>$ ttabel $(1,985)$ dan sig 0,000 < 0,05 maka H0 ditolak Ha diterima yang maksudnya Kepuasan Konsumen (Z) berpengaruh secara signifikan terhadap Loyalitas Konsumen (Y).

\section{Koefisien Determinasi}

Berdasarkan Model Summary besar nilai R square 0,712 atau dengan perhitungan rumus koefisien determinasi yaitu:

$$
\begin{aligned}
&\left.\mathrm{KD}_{\text {Sub-Struktur } 2=R^{2} \times 100 \%=(0,844}\right)^{2} \times 100 \% \\
&= 0,712 \times 100 \% \\
&= 71,2 \%
\end{aligned}
$$

Artinya adalah besarnya pengaruh variabel Kualitas Layanan $\left(X_{1}\right)$, Citra Perusahaan $\left(X_{2}\right)$ dan Kepuasan Konsumen (Z) terhadap Loyalitas Konsumen (Y) sebesar 71,2\%, dan sisanya $28,8 \%$ dipengaruhi oleh variabel lain.

Model hubungan berdasarkan analisis sub-stuktur 1 dan 2, secara keseluruhan digambarkan sebagai berikut: 


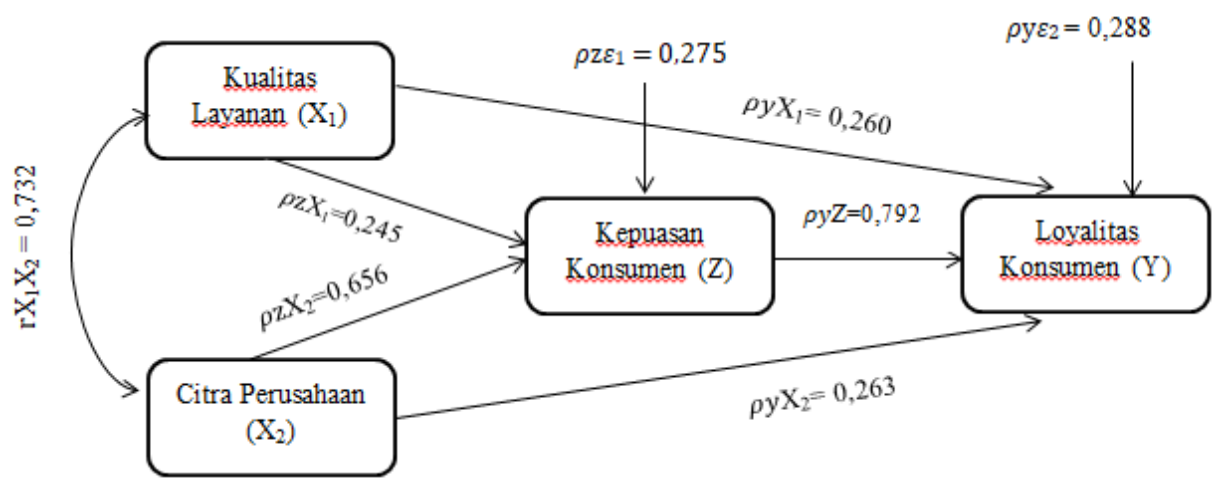

Gambar 3.1 Hubungan Kausal Sub-Struktur 1 dan 2

\subsection{Pembahasan}

Berdasarkan hasil analisis deskriptif, Kualitas Layanan Lion Air secara keseluruhan masuk kategori cukup baik dan besar persentase $65 \%$. Variabel Citra Perusahaan masuk pada kategori cukup baik dan besar persentase 62,6\%. Variabel Kepuasan Konsumen berada pada kategori cukup baik dengan besar persentase 58,2\%. Dan Loyalitas Konsumen masuk pada kategori tidak baik dan besar persentase $51,4 \%$.

Hasil uji sub-struktur 1 diperoleh nilai $F$ hitung sebesar $(128,160)>F$ tabel $(2,47)$ dengan nilai probabilitas (sig) $=0,000<0,05$ maka $\mathrm{H}_{\mathrm{o}}$ ditolak dan $\mathrm{H}_{\mathrm{a}}$ diterima yang maksudnya secara bersama-sama Kualitas Layana $\left(\mathrm{X}_{1}\right)$ dan Citra Perusahaan $\left(\mathrm{X}_{2}\right)$ berpengaruh secara simultan dan signifikan terhadap Kepuasan Konsumen (Z). Hasil uji secara parsial, variabel Kualitas Layanan $\left(\mathrm{X}_{1}\right)$ nilai thitung $(3,137)>\mathrm{t}$ tabel $(1,985)$ dengan sig $0,002<0,05$ maka $\mathrm{H}_{0}$ ditolak dan $\mathrm{H}_{\mathrm{a}}$ diterima yang artinya Kualitas Layanan $\left(\mathrm{X}_{1}\right)$ berpengaruh secara signifikan terhadap Kepuasan Konsumen $(\mathrm{Z})$. Variabel Citra Perusahaan $\left(\mathrm{X}_{2}\right)$ nilai t hitung $(8,408)>\mathrm{t}$ tabel $(1,985)$ dengan sig $0,000<0,05$ maka $\mathrm{H}_{0}$ ditolak dan $\mathrm{H}_{\mathrm{a}}$ diterima yang artinya Citra Perusahaan $\left(\mathrm{X}_{1}\right)$ berpengaruh secara signifikan terhadap Kepuasan Konsumen (Z). Besarnya nilai R square adalah 0,725 atau $72,5 \%$ artinya besar pengaruh variabel dari Kualitas Latanan $\left(\mathrm{X}_{1}\right)$ dan Citra Perusahaan $\left(\mathrm{X}_{2}\right)$ terhadap Kepuasan Konsumen (Z), dan 27,5\% sisanya dipengaruhi variabel lain.

Hasil uji sub-struktur 2 diperoleh $F$ hitung $(79,143)>$ Ftabel $(2,47)$ dengan nilai siq $0,000<$ 0,05 maka $\mathrm{H}_{0}$ ditolak dan $\mathrm{H}_{\mathrm{a}}$ diterima yang maksudnya adalah secara bersama-sama Kualitas Layanan (X1), Citra Perusahaan (X2) dan Kepuasan Konsumen (Z) berpengaruh secara simultan dan signifikan terhadap Loyalitas Konsumen (Y). hasil uji secara parsial Variabel Kualitas Layanan $\left(\mathrm{X}_{1}\right)$ nilai t hitung $(3,084)>$ ttabel $(1,985)$ dengan sig $0,003<0,05$ maka $\mathrm{H}_{0}$ ditolak dan $\mathrm{H}_{\mathrm{a}}$ diterima yang artinya Kualitas Layanan $\left(\mathrm{X}_{1}\right)$ berpengaruh signifikan terhadap Loyalitas Konsumen $(\mathrm{Y})$. Variabel Citra Perusahaan $\left(\mathrm{X}_{2}\right)$ nilai t hitung $(2,486)>t$ tabel $(1,985)$ dengan sig 0,015>0,05 maka H0 ditolak dan Ha diterima yang artinya Citra Perusahaan $\left(\mathrm{X}_{2}\right)$ berpengaruh secara signifikan terhadap Loyalitas Konsumen (Y). Variabel Kepuasan Konsumen (Z) nilai $\mathrm{t}$ hitung $(7,573)>\mathrm{t}$ tabel $(1,985)$ dengan sig $0,000<0,05$ maka $\mathrm{H}_{\mathrm{o}}$ ditolak $\mathrm{H}_{\mathrm{a}}$ diterima yang artinya Kepuasan Konsumen ( $\mathrm{Z}$ ) berpengaruh secara signifikan terhadap Loyalitas Konsumen ( $\mathrm{Y}$ ). Besarnya nilai $\mathrm{R}$ square adalah 0,712 atau $71,2 \%$ artinya besarnya pengaruh variabel Kualitas Layanan $\left(\mathrm{X}_{1}\right)$, Citra Perusahaan $\left(\mathrm{X}_{2}\right)$ dan Kepuasan Konsumen $(\mathrm{Z})$ terhadap Loyalitas Konsumen (Y) sebesar 71,2\%, dan 28,8\% sisanya dipengaruhi oleh variabel diluar penelitian ini..

\section{PENUTUP}

\section{Kesimpulan}

a. Kualitas Layanan Lion Air masuk pada kategori cukup baik.

b. Citra Perusahaan Lion Air masuk pada kategori cukup baik.

c. Kepuasan Konsumen Lion Air masuk dalam kategori cukup baik.

d. Loyalitas Konsumen Lion Air masuk dalam kategori tidak baik. 
e. Kualitas Layanan dan Citra Perusahaan berpengaruh secara simultan dan signifikan terhadap Kepuasan Konsumen Lion Air di kota Bandung.

f. Kualitas Layanan, Citra Perusahaan secara parsial signifikan terhadap Kepuasan Konsumen Lion Air di Kota Bandung.

g. Kualitas Layanan, Citra Perusahaan dan Kepuasan Konsumen secara simultan dan signifikan terhadap Loyalitas Konsumen Lion Air di kota Bandung.

h. Kualitas Layanan, Citra Perusahaan dan Kepuasan Konsumen secara parsial signifikan terhadap Loyalitas Konsumen Lion Air di Kota Bandung.

i. Berdasarkan hasil perhitungan koefisien jalur variabel Kualitas Layanan dan Citra Perusahaan secara bersama-sama berpengaruh terhadap variabel Loyalitas Konsumen melaui Kepuasan.

\section{F. DAFTAR PUSTAKA}

Abdul Majid, Suharto,(2018). Customer Service Dalam Bisnis Jasa Transportasi. Depok: Rajawali Pers.

Dewi Kusuma, Hilda. (2018). Pengaruh Kualitas Layanan \&Citra Perusahaan terhadap Loyalitas Nasabah dengan Kepuasan Sebagai Intervening Variable (Studi Kasus Pada BPRS Suriyah Semarang. Skripsi pada Institut Agama Islam Negeri Salatiga.

Finnora, Elza \& Razak, Ismail. (2017). Pengaruh Kualitas Layanan dan Citra Perusahaan terhadap Kepuasan Nasabah. Jurnal Manajemen Bisnis Krisnadwpayana. Vol 5. No. 2.

Iidh Arima, Sesria \& dkk (2018). Pengaruh Kualitas Layanan Terhadap Loyalitas Pelanggan Lion Air di Kota Padang. Jurnal RAP UNP, Vol 9. No 1.

Indrawati. (2015). Metode Penelitian Manajemen dan Bisnis Konvergensi Teknologi Komunikasi dan Informasi. Bandung: PT Refika Aditama.

Kotler,P.,\& Keller, L. K (2016). Marketing Manajemen. USA: Pearson Education Limited.

Rai Utama, I Gusti Bagus. (2017). Pemasaran Pariwisata. Yogyakarta. CV. Andi Offset.

Safitri, Erwina \& dkk. (2016) Pengaruh Kualitas Pelayanan dan Citra Perusahaan terhadap Kepuasan dan Loyalitas Pelanggan Service Center (Studi pada Pelanggan Samsung Service Center di Kota Malang). Jurnal Ekonomi Bisnis. No.1.

Sarwono, Jonathan. (2012). Analisis Jalur untuk Riset Bisnis SPSS. Yogyakarta: C.V Andi Offset.

Sarwono, Jonathan. (2012). Path Analysis. Jakarta. PT. Elex Media.

Sugiyono. (2012). Metode Penelitian Bisnis (Pendekatan Kuantitatif, Kualitatif, dan R\&D). Bandung: Alfabeta.

Sugiyono. (2014). Metode Kuantitatif, Kualitatif, dan Kombinasi (Mixed Methods). Bandung: Alfabeta.

Sugiyono. (2019). Metode Penelitian Kuantitatif, Kualitatif, R\&D. Bandung: ALFABETA.

Sulibhavi, Basavaraj \& Shivashankar. (2017). The Impact Of Brand Image On Customer'S Loayalty Towards Private Label Brands : The Mediating Effect Of Satisfaction. HubliDharwad Conglomerate City Of Karnataka. International Journal of Marketing \& Financial Management. Vol 5, Issue 8.

Sulselsatu. (2018). https://www.sulselsatu.com. Buruknya Pelayanan Lion Air dari Delay Hingga Mati Mesin Menyiksa Penumpang. (diakses 19 Oktober 2019).

Suratno \& dkk. (2016). Pengaruh Citra Perusahaan dan Kualitas Pelayanan terhadap Loyalitas Pelanggan dengan Kepuasan Pelanggan sebagai Variabel Intervening pada PT Pelabuhan Indonesia III Semarang. Journal of Management, Vol 2 No.2.

Tirto.id, (2019). https://tirto.id. BenarkahLion Air merugi. (diakses 29 Oktober 2019)

Tjiptono, Fandy \& Chandra, Gregorius.( 2017). Pemasaan Strategik . Yogyakarta: ANDI

Windasuri,Heria \& dkk. (2016). The Secrets of Building Organization. Jakarta: PT Gramedia Pustaka Utama. 